\title{
PENINGKATAN KOMPETENSI PEDAGOGIK GURU MELALUI PELATIHAN PAIKEM (PELATIHAN PADA GURU MI DAN MTS DI KABUPATEN CIANJUR)
}

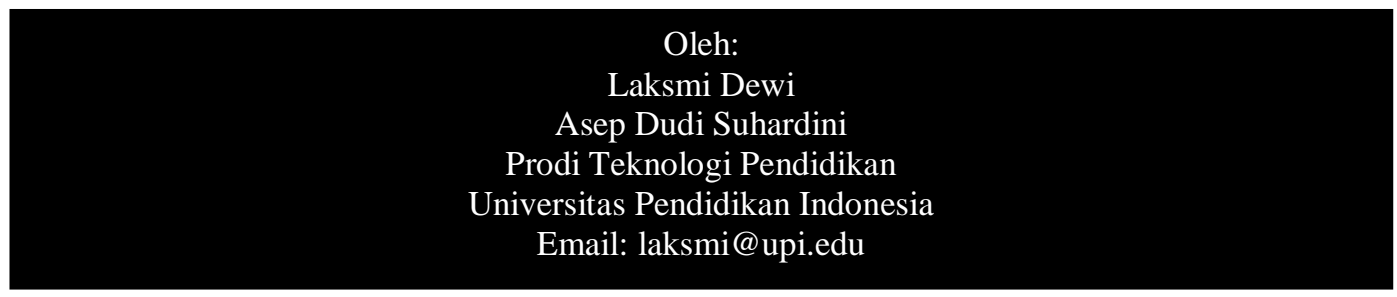

Abstract. Learning is not monopoly of teachers (teacher centered). The teacher in charge of teaching and, especially, the students who do learning activities, both have the same right to manage their learning process with its various components. Teachers should have the pedagogic skills makes the students learn. Pedagogical competence of teachers need to be trained to increase their skills, so that teachers are able to create an active learning, innovative, creative, effective and fun for students. Successful training is training that can provide added value to knowledge, attitudes and skills of the participants. Good training is training that suits participants needs and its results can be applied in paraticipants workplace. PAIKEM training which has been implemented successfully contribute to the improvement of pedagogical competence of the participants.

Keywords: effective training, relevance, improving the competence of teachers

Abstrak. Pembelajaran bukanlah monopoli guru (teacher centered). Guru yang bertugas mengajar dan, terutama, peserta didik yang melakukan kegiatan belajar, keduanya memiliki hak yang sama untuk mengelola proses pembelajaran dengan berbagai komponennya. Untuk itulah guru harus memiliki keterampilan pedagogik membuat siswa belajar. Kompetensi pedagogik guru perlu dilatih agar keterampilannya meningkat, sehingga guru mampu menciptakan pembelajaran yang aktif, inovatif, kreatif, efektif dan menyenangkan untuk peserta didik. Pelatihan yang berhasil adalah pelatihan yang dapat memberikan nilai tambah pada pengetahuan, sikap dan keterampilan peserta. Pelatihan yang baik adalah pelatihan yang sesuai dengan kebutuhan peserta dan hasilnya dapat diterapkan di dunia kerja peserta. Pelatihan PAIKEM yang telah dilaksanakan ini berhasil memberikan sumbangan bagi peningkatan kompetensi pedagogik para peserta.

Kata Kunci : pelatihan efektif, relevansi, peningkatan kompetensi guru

\section{A. PENDAHULUAN}

Peningkatan kualitas pendidikan adalah inti permasalahan sistem pendidikan di Indonesia dari masa ke masa, mulai dari jenjang pendidikan dasar, menengah, hingga pendidikan tinggi. Banyak upaya telah dilakukan pemerintah dalam rangka meningkatkan kualitas pendidikan, diantaranya melalui kebijakan.
Kebijakan yang saat ini diberlakukan adalah pemenuhan Standar Nasional Pendidikan. Kebijakan ini diterapkan pada sekolah/ madrasah pada jenjang pendidikan dasar dan menengah.

Madrasah adalah sekolah formal yang bercirikan Islam. Jenjang pendidikan formal madrasah terdiri atas Madrasah Ibtidaiyah (MI), Madrasah Tsanawiyah 
(MTs), dan Madrasah Aliyah (MA). Berdasarkan data statistik, pendidikan madrasah secara nasional meliputi 23.939 MI, 13.292 MTs, dan 5.648 MA (Pendis; 2013). Dari jumlah madrasah sebanyak itu, pada umumnya didirikan dan dikelola oleh masyarakat (swasta).

Pola pendidikan madrasah yang dikelola oleh masyarakat, memiliki kecenderungan performansi yang unik, baik dalam hal kepemimpinan pendidikan, pengelolaan kelembagaan, distribusi sumber daya manusia, keterbatasan sumber daya material dan sumber dana, lingkungan sosial-ekonomi dan sosialbudaya, partisipasi masyarakat, juga motif dan orientasi pendirian madrasah. Kekhasan madrasah pada kurun waktu sebelumnya seringkali dikaitkan dengan penilaian madrasah sebagai sekolah "kelas dua". Namun pada dekade terakhir pendapat tersebut dapat diperbandingkan dengan kenyataan yang berbeda. Thaib (2014: 1) menyampaikan bahwa "tingkat kelulusan hasil ujian nasional siswa MTs 99,683\% dan kualitas yang mereka capai 7.48 sudah jauh diatas nilai nominal SMP”. Hasil penelitian yang dilakukan Hasbi (2013:387) menyimpulkan bahwa "secara umum dalam pelaksanaan sistem pendidikannya madrasah telah memenuhi 8 (delapan) Standar Nasional Pendidikan”.

Peningkatan kualitas pendidikan dipengaruhi oleh proses pembelajaran yang dilaksanakan di kelas. Guru dan siswa adalah aktor utama dalam pelaksanaan pembelajaran. Dalam konteks ini, guru sering disebut sebagai ujung tombak pelaksanaan pembelajaran. Guru yang baik dalam pembelajaran adalah guru yang dapat mengelola pembelajaran "dari hulu sampai ke hilir" proses pembelajaran. Perencanaan pembelajaran yang matang akan memberikan dampak hasil pembelajaran yang efektif sesuai dengan yang diharapkan. Kemampuan guru dalam mengembangkan materi, media, metode, pola evaluasi dan memanipulasi lingkungan belajar menjadi salah satu kunci meningkatkan partisipasi belajar aktif siswa. Kemampuan tersebut merupakan salah satu kompetensi pedagogik yang harus dimiliki oleh setiap guru.

Diantara masalah krusial di madrasah adalah ketersediaan guru dalam jumlah yang memadai, ketidaksesuaian latar pendidikan guru dengan mata pelajaran yang diampunya (mismatch), ketersediaan guru yang memiliki latar ilmu kependidikan (didaktik-metodik) dan memiliki ijazah mengajar, dan sertifikasi pendidik bagi guru. Masalah-masalah keguruan ini berdampak pada kapasitas dan kapabilitas guru dalam mengelola proses pembelajaran. Akhirnya, hal ini bermuara pada kualitas pembelajaran di madrasah. 
Kompetensi pedagogik guru madrasah sebagai core competency kependidikan perlu ditingkatkan secara berkala. Pembiaran guru dengan kompetensi yang ada atau seadanya dalam mengelola kegiatan pembelajaran adalah sebuah bentuk "penyimpangan akademik". Guru tidak sepantasnya dibiarkan melakukan tindakan otodidak, melainkan perlu diintervensi sebagai upaya meningkatkan kompetensinya. Untuk itu pelatihan Pembelajaran Aktif, Inovatif, Kreatif, Efektif dan Menyenangkan (PAIKEM) menjadi menu wajib dalam upaya meningkatkan kualitas proses pembelajaran. Sebagai pilot project pelatihan tersebut diberikan kepada sejumlah guru madrasah di Ciamis, Tasikmalaya, Garut dan Cianjur dalam kurun dua tahun terakhir. Dampak pelatihan terhadap peningkatan kompetensi pedagogik peserta ditunjukkan dalam tulisan berikut ini.

Tujuan dari penelitian ini adalah bagaimana efektivitas pelaksanaan pelatihan PAIKEM yang diselenggarakan bagi guru-guru MI dan MTs memberikan pengaruh terhadap peningkatan kompetensi pedagogis guru dalam melaksanakan proses pembelajarannya.

\section{Metode Pengumpulan Data}

Kegiatan ini dilakukan dengan melakukan pelatihan kepada 47 guru dari 24 madrasah (MI dan MTs ) yang ada di
Kabupaten Cianjur. Para guru diberikan wawasan dan praktek selama 3 hari tentang PAIKEM. Sebelum dan sesudah pelatihan peserta diberikan tes (pre-post test). Kegiatan pelatihan dilakukan dengan pemberian konsep dan praktek secara seimbang. Di sesi terakhir setiap peserta melakukan praktik mengajar dengan teman sebaya (peer teaching).

Instrumen yang digunakan pada penelitian ini adalah tes, lembar pengamatan, dan isian kuesioner terhadap pelaksanaan pelatihan. Tes, digunakan untuk mengukur kemampuan peserta diklat sebelum dan sesudah pelatihan. Lembar pengamatan digunakan untuk menilai performance guru dalam melakukan praktik mengajar. Sedangkan isian kuesioner digunakan untuk mengetahui pendapat peserta diklat terhadap pelatihan yang dilakukan.

\section{B. HASIL DAN PEMBAHASAN}

PAIKEM merupakan sebuah format pembelajaran yang memungkinkan peserta didik mengerjakan kegiatan yang beragam dalam rangka mengembangkan keterampilan dan pemahamannya. Model pembelajaran ini menekankan peran aktif peserta didik untuk melakukan kegiatan belajar, sementara guru menggunakan berbagai sumber dan alat bantu belajar (termasuk pemanfaatan lingkungan), sehingga pembelajaran lebih menarik, menyenangkan dan efektif. Hal ini 
sebagaimana dinyatakan dalam PP No. 19 tahun 2005 BAB IV pasal 19 ayat 1 yang menyatakan bahwa "proses pembelajaran pada satuan pendidikan diselenggarakan secara interaktif, inspiratif, menyenangkan, menantang, memotivasi peserta didik untuk berpartisipasi aktif serta memberikan ruang yang cukup bagi prakarsa, kreatifitas dan kemandirian sesuai dengan bakat, minat, dan perkembangan fisik serta psikologis peserta didik". Lebih jelas lagi mengenai hal ini diatur dalam Peraturan Menteri Pendidikan Nasional No 41 Tahun 2008 tentang Standar Proses. Konsekuensi dari ha-hal tersebut adalah tuntutan dan tantangan agar guru menyelenggarakan pembelajaran yang aktif, kreatif, inovatif, efektif dan menyenangkan (PAIKEM).

Penerapan PAIKEM diharapkan memberikan kemudahan bagi peserta didik dalam memahami materi pelajaran yang disampaikan oleh guru. Untuk itu guru dituntut untuk kreatif dan inovatif dalam menciptakan suasana belajar yang menyenangkan. Diantaranya dengan kemampuan guru mengemas suatu materi pelajaran melalui pemanfaatan berbagai media dan sumber belajar. Kemasan guru tersebut diharapkan menghasilkan proses pembelajaran yang menyenangkan dan bermakna bagi peserta didik.
Berdasarkan efek size pelatihan pada peserta dapat dipastikan bahwa pelatihan PAIKEM pada guru MI dan MTs peserta pelatihan memberikan peningkatan kompetensi kognitif pedagogik yang besar. Hal ini bertitik tolak pada realitas di madrasah-madrasah tempat para peserta melaksanakan fungsi keguruannya, bahwa pada umumnya mempunyai problem krusial sumber daya manusia pendidik. Sebagaimana diuraikan sebelumnya bahwa madrasah menghadapi kondisi: a. keterbatasan sumber daya guru yang memadai, b. ketidaksesuaian latar pendidikan guru dengan bidang pelajaran yang diampu, c. guru tanpa dasar disiplin ilmu kependidikan, dan d. guru belum tersertififkasi. Keterbatasan ini dapat diindikasikan oleh pengetahuan guru mengenai wawasan didaktik metodik mengelola pendidikan pembelajaran, menyusun desain pembelajaran, mengelola kelas dan keterampilan mengembangkan materi, media, metode dan teknik evaluasi dalam pembelajaran. Pelatihan PAIKEM memberikan sejumlah pengetahuan mengenai wawasan keguruan, model pembelajaran pendekatan dan langkahlangkahnya, disertai dengan simulasi pembelajarannya. 


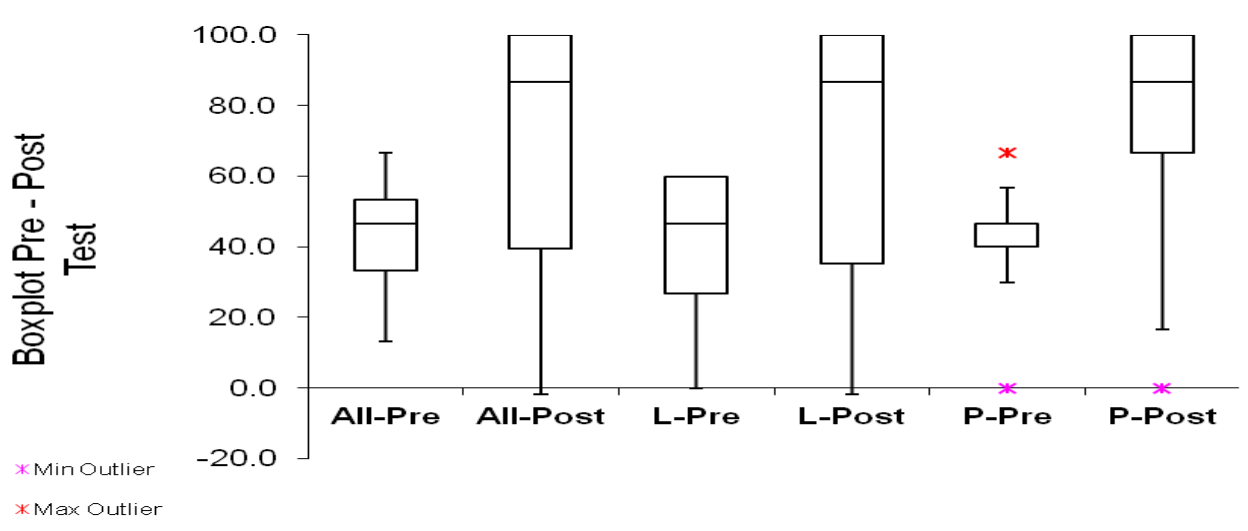

Grafik 1. Perbandingan Pre-post Test

Pelaksanaan pelatihan berlangsung peserta sebagai subyek aktif. Berdasarkan secara efektif. Hal ini ditunjukkan dengan pengamatan, peserta menunjukkan penilaian peserta melalui angket terhadap antusiasme dan tingkat partisipasi yang berbagai komponen pelatihan secara tinggi pada saat pelatihan berlangsung. komprehensif yaitu kerangka dan isi materi Dalam pelatihan yang melibatkan peserta pelatihan, kemampuan pelatih dalam secara aktif, mendorong peserta untuk mengelola pelatihan, pemilihan metode kreatif dan penciptaan suasana yang dan teknis pelatihan, penggunaan alat menyenangkan cenderung menghasilkan bantu media, pengelolaan setting tingkat belajar yang cukup bermakna. lingkungan pelatihan serta pelibatan

\begin{tabular}{|c|c|c|c|c|c|c|}
\hline \multirow{2}{*}{$\begin{array}{c}\text { Pre \& Post } \\
\text { Test }\end{array}$} & \multicolumn{2}{|c|}{$\sum: \mathbf{4 7}$} & \multicolumn{2}{c|}{ L : 22 } & \multicolumn{2}{|c|}{ P : 25 } \\
\cline { 2 - 7 } Mean & 43.1 & 71.9 & 41.2 & 65.1 & 40.6 & 77.8 \\
\hline Stdev & 14.3 & 45.6 & 19.6 & 39.5 & 15.0 & 50.6 \\
\hline Tost & Pre test & 0.0000000 & 0.0000004 & 0.0000 \\
\hline $\begin{array}{c}\text { Ada } \\
\text { Perubahan }\end{array}$ & \multicolumn{2}{|c|}{ Yast } & \multicolumn{2}{|c|}{ Pre } & Post \\
\hline Efect Size & 2.009268 & \multicolumn{2}{|c|}{1.2206} & Ya \\
\hline Efektifitas & \multicolumn{2}{|c|}{ Besar } & \multicolumn{2}{|c|}{ Besar } & \multicolumn{2}{|c|}{ Besar } \\
\hline
\end{tabular}

Grafik 2. Tingkat perubahan dan efektifitas pelatihan

Pelatihan PAIKEM sangat diperlukan para guru untuk meningkatkan oleh para peserta karena sangat dibutuhkan keterampilannya mengelola pembelajaran. 


\begin{tabular}{|c|c|c|c|c|c|c|}
\hline \multicolumn{2}{|c|}{ Kelompok } & Pertanyaan & $\begin{array}{c}\text { Sangat Baik } \\
\text { dan Baik }\end{array}$ & Cukup & Kurang & $\begin{array}{l}\text { Sangat } \\
\text { Kurang }\end{array}$ \\
\hline Relevan & $\sqrt{ }$ & $1 \& 6$ & $93.5 \%$ & $6.5 \%$ & $0.0 \%$ & $0.0 \%$ \\
\hline Efektif & $\sqrt{ }$ & $2,3,4,5$ & $96.2 \%$ & $3.8 \%$ & $0.0 \%$ & $0.0 \%$ \\
\hline
\end{tabular}

Grafik 3. Relevansi dan efektivitas pelatihan

Secara umum pelatihan PAIKEM memberikan relevan dan efektif yang sangat baik bagi para guru di MI dan MTs di Kabupaten Cianjur. Prose pelatihan yang dilakukan juga dengan mengikuti pola prinsip pembelajaram PAIKEM, dimana proses pembelajaran lebih menekankan pada proses pelatihan yang melibatkan peserta pelatihan secara aktif. Hal ini sesuai dengan prinsip pembelajaran PAIKEM dapat dijabarkan sebagai berikut: (1) Pembelajaran aktif, siswa tidak hanya berperan sebagai pendengar saja. Mereka selalu diberi kesempatan untuk menyampaikan gagasannya. Semua aspek keaktifan siswa dioptimalkan; pembelajaran inovatif, pembelajaran di kelas tidak selalu menggunakan modelmodel pembelajaran konvensional. Guru dituntut untuk berinovasi dengan menggunakan model-model pembelajaran yang menyenangkan. (3) pembelajaran kreatif, pembelajaran kreatif berkaitan dengan pengembangan daya imajinasi dan kreatifitas siswa. Guru mengakomodir siswa untuk mengungkapkan isi pikirannya, atau menuangkan ide-idenya.
(4) pembelajaran efektif, walaupun kegiatan pembelajaran sudah menjadi aktif dan menyenangkan, tujuan utama pembelajaran tidak boleh dilupakan sama sekali. Guru harus senantiasa memperhitungkan dampak instruksional dan dampak pengiring dari kegiatan pembelajaran;

(5) pembelajaran menyenangkan, pembelajaran di dalam kelas harus diupayakan sedemikian rupa agar terasa menggairahkan dan menantang murid untuk belajar.

Prinsip penerapan PAIKEM adalah sebagai berikut: (1) Mengalami: peserta didik terlibat secara aktif baik fisik, mental maupun emosional. Melalui pengalaman langsung pembelajaran akan lebih memberi makna kepada siswa daripada hanya mendengarkan. Misalnya pada mata pelajaran olah raga, supaya siswa dapat mengetahui tentang bagaimana melakukan serve dalam permainan bola voli, maka guru memberikan kesempatan kepada siswanya untuk melakukan serve bola, (2) Komunikasi: kegiatan pembelajaran memungkinkan terjadinya komunikasi antara guru dan peserta didik. Proses lalui Pelatihan Paikem (Pelatihan Pada Guru Mi 414 Peningkatan Kompetensi Pedagogik Guru Melalui Pelatihan Paikem (Pelatihan Pada Guru Mi Dan Mts Di Kabupaten Cianjur) 
komunikasi yang baik adalah proses ini guru diminta melakukan praktek komunikasi dimana antara unsur pembelajaran dengan menggunakan komunikator dan komunikan terdapat satu pembelajaran PAIKEM. Antusiasme guru arah yang sama, (3) Interaksi: kegiatan sangat luar biasa. Kemampuan guru pembelajarannya memungkinkan mengkesplorasi berbagai metode terjadinya interaksi multi arah. Interaksi pembelajaran terlihat cukup variatif. multi arah yang diharapkan terjadi adalah Pemilihan berbagai metode pembelajaran interaksi transaksional, dimana proses komunikasi antara guru dengan siswa, siswa dengan guru, siswa dengan siswa, bahkan siswa dengan lingkungan sekitar memiliki kesiapan yang cukup baik, (4)

Refleksi: kegiatan pembelajarannya memungkinkan peserta didik memikirkan kembali apa yang telah dilakukan. Proses refleksi sangat perlu dilakukan untuk mengetahui sejauhmana ketercapaian proses pembelajaran. Kegiatan refleksi ini dilakukan bersama antara guru dengan siswa (Masitoh \& Laksmi, 2009: 9.13).

Gambaran pelaksanaan strategi PAIKEM, dapat terlihat dari kegiatankegiatan yang terjadi selama pembelajaran di kelas. Baik kegiatan yang dilakukan oleh guru, maupun oleh peserta didiknya. Kemampuan guru akan sangat berpengaruh dalam pelaksanaan strategi ini, karena seaktif apapun siswa, gurulah yang tetap memegang kendali dari proses pembelajaran yang sedang berlangsung. Pelatihan PAIKEM yang diberikan kepada guru, diharapkan memberikan pengaruh yang positif tehadap perubahan kompetensi merupakan bagian dari salah satu kompetensi guru, yaitu kompetensi pedagogic.

Kompetensi pedagogik seorang guru guru dapat tercermin pada pemberian pelayanan terbaik saaat melaksanakan proses pembelajaran. Kompetensi pedagogik guru berhubungan dengan kemampuan guru mengelola kegiatan pembelajaran. Kompetensi ini melibatkan unsur pengetahuan guru, sikap dan keterampilannya dalam mengembangkan proses mengajar yang dilaksanakannya dan proses belajar yang dilakukan peserta didik. Kemampuan ini meliputi tujuh bidang seperti yang dijabarkan pada Peraturan Pemerintah No 74 Tahun 2008 tentang Guru, yaitu: 1. memahami karakteristik para peserta didik, 2. menguasai konsep-konsep belajar dan prinsip-prinsip pembelajaran yang mendidik, 3. memahami dan mengembangkan kurikulum, 4. melaksanakan kegiatan pembelajaran yang mendidik, 5. mengembangkan potensi peserta didik, 6. menciptakan komunikasi pedagogic guru MI/MTs. Melalui pelatihan 
edukaif dengan peserta didik, dan 7. metode pembelajaran, mengelola kelas melaksanakan penilaian dan evaluasi.

$$
\text { Pemahaman guru terhadap }
$$
dengan efektif, memberikan kesempatan karakteristik fisik, intelektual, sosial, untuk bertanya, mempraktekkan dan emosional, moral, dan latar belakang sosial budaya diharapkan akan membantu mengoptimalkan kegiatan pembelajaran. Keluaran dari pemahaman ini adalah peserta didik: mendapatkan kesempatan yang sama untuk berpartisipasi aktif walaupun ada sejumlah perbedaan, tidak dirugikan karena guru bisa mengantisipasi munculnya perilaku negatif, terdorong untuk mengembangkan potensi secara optimal dan dapat mengatasi kekurangannya, mendapatkan perlakukan yang adil dab nyaman dalam mengikuti pembelajaran walaupun memiliki kendala.

Dalam kaitannya dengan kurikulum, guru dituntut untuk mampu melaksanakan kegiatan pembelajaran sesuai dengan rancangan silabus dan RPP yang dibuatnya. Rancangan yang disusunnya haruslah mempertimbangkan berbagai komponen belajar siswa sesuai dengan kurikulum yang sudah ditetapkan.

Dalam pelaksanaan rancangan pembelajaran, guru harus mampu melaksanakan rancangan pembelajaran secara lengkap, sesuai dengan kebutuhan peserta didik, materi pembelajaran dan sumber belajar yang tepat, mengkaitkannya dengan konteks berinteraksi dengan sesama peserta didik, mengatur pelaksanaan aktivitas pembelajaran secara sistematis, dan menggunakan alat bantu media mengajar yang sesuai. Melalui pembelajaran PAIKEM kebutuhan belajar siswa yang beragam dapat diakomodasi melalui penggunaan berbagai metode dan media pembelajaran yang bervariatif.

Guru harus mampu mengidentifikasi minat, bakat, potensi dan kesulitan belajar peserta didik serta upaya aktualisasi dan pengembangan. Berkaitan dengan hal ini guru perlu merancang dan melaksanakan pembelajaran untuk memunculkan daya kreativitas dan daya kritis, sesuai dengan kecakapan dan pola belajar, Guru secara aktif membantu peserta didik dalam proses pembelajaran dengan memberikan perhatian kepada setiap individu. Kemampuan mengembangkan komunikasi yang efektif dengan peserta didik sangat diperlukan. Kemampuan berkomunikasi efektif meliputi sejumlah keterampilan, seperti: memberikan respon, menggunakan pertanyaan, memberi perhatian, mendengarkan, mengklarifikasi pertanyaan/tanggapan, menanggapi kehidupan sehari-hari, melakukan variasi 416 Peningkatan Kompetensi Pedagogik Guru Melalui Pelatihan Paikem (Pelatihan Pada Guru Mi Dan Mts Di Kabupaten Cianjur) 
Kompetensi guru berikutnya adalah kemampuan melakukan penilaian baik proses maupun hasil pembelajaran yang dilaksanakannya. Hal ini penting sebagai balikan (feedback) bagi perbaikan rancangan pembelajarannya. Untuk itu guru perlu memiliki keterampilan menyusun instrument penilaian yang tepat sejalan dengan tujuan pembelajaran, melaksanakan penilaian, dan menggunakan hasil penilaian tersebut untuk mengoptimalkan belajar peserta didik dan penyempurnaan proses pembelajaran.

Terdapat banyak cara yang dapat dilakukan oleh guru saat menerapkan pembelajaran PAIKEM dalam proses pembelajaran. Berikut adalah contoh beberapa kegiatan yang dapat dilakukan dalam pelaksanaan strategi PAIKEM:

\section{Kemampuan Guru}

\section{Pembelajaran}

\begin{tabular}{|c|c|}
\hline $\begin{array}{l}\text { Guru menggunakan alat bantu dan } \\
\text { sumber belajar yang beragam }\end{array}$ & $\begin{array}{l}\text { Sesuai mata pelajarannya, guru dapat } \\
\text { menggunakan beragam alat bantu belajar/media } \\
\text { pembelajaran, misalnya: } \\
\text { - Gambar; } \\
\text { - Lingkungan; } \\
\text { - Alat peraga dll. }\end{array}$ \\
\hline $\begin{array}{l}\text { Guru memberi kesempatan kepada } \\
\text { siswa untuk mengungkapkan } \\
\text { gagasannya sendiri secara lisan } \\
\text { atau tulisan. }\end{array}$ & $\begin{array}{l}\text { - Guru mengajak diskusi; } \\
\text { - Guru melontarkan pertanyaan-pertanyaan } \\
\text { yang memancing jawaban siswa; } \\
\text { - Guru memberikan kepercayaan kepada siswa } \\
\text { untuk memaparkan gagasannya kepada } \\
\text { teman-teman kelasnya dll. }\end{array}$ \\
\hline $\begin{array}{l}\text { Guru menyesuaikan bahan dan } \\
\text { kegiatan belajar dengan } \\
\text { kemampuan siswa. }\end{array}$ & $\begin{array}{l}\text { - Guru mengelompokkan siswa sesuai dengan } \\
\text { kriteria tertentu, kemudian memberikan } \\
\text { bahan pelajaran yang sesuai dengan anggota- } \\
\text { anggota kelompok tersebut; } \\
\text { - Guru memberikan kesempatan kepada siswa } \\
\text { untuk memperbaik nilai/kemampuannya } \\
\text { melalui tugas tambahan/pengayaan. }\end{array}$ \\
\hline $\begin{array}{l}\text { Guru mengaitkan pembelajaran } \\
\text { dengan pengalaman siswa sehari- } \\
\text { hari. }\end{array}$ & $\begin{array}{l}\text { - Guru memberikan kesempatan kepada siswa } \\
\text { untuk menceritakan pengalamannya sehari- } \\
\text { hari; } \\
\text { - Guru memberikan contoh aplikasi nyata } \\
\text { dalam kehidupan sehari-hari dari materi } \\
\text { pelajaran yang sedang diterangkan. }\end{array}$ \\
\hline $\begin{array}{l}\text { Guru menilai pembelajaran dan } \\
\text { kemajuan belajar siswa secara } \\
\text { terus menerus. }\end{array}$ & $\begin{array}{l}\text { - Guru memantau dan mengevaluasi kinerja } \\
\text { siswa; } \\
\text { - Guru memberikan bimbingan/motivasi dan } \\
\text { saran-saran kepada siswa untuk dpat } \\
\text { meningkatkan prestasinya. }\end{array}$ \\
\hline
\end{tabular}




\section{SIMPULAN}

Pelatihan PAIKEM bagi guru-guru MI dan MTs di lingkungan Kabupaten Cianjur, terlaksana dengan cukup baik memberikan dampak terhadap peningkatan pengetahuan peserta pelatihan. $\mathrm{Hal}$ ini terlihat dari hasil pre dan pos tes yang terjadi peningkatan hasil belajar. Hal ini dapat dilihat berdasarkan pengamatan secara umum guru-guru ikut "hanyut" pada pelatihan PAIKEM yang cukup menarik. Pelatihan ini menggunakan berbagai metode pembelajaran, sehingga peserta pelatihan tidak merasa bosan. Peserta pelatihan terlibat secara aktif dalam pelaksanaan, sehingga masalah yang diangkat betul-betul real yang dialami oleh peserta pelatihan. Berdasarkan hasil angket yang disampaikan dapat disimpulkan bahwa peserta pelatihan merasakan manfaat bahwa pelatihan PAIKEM ini dapat diterapkan ketika para guru kembali ke madrasah dan melaksanakan proses pembelajaran di kelas.

Pelatihan PAIKEM ini diharapkan tidak hanya berhenti setelah pelatihan selesai. Diharapkan para guru dapat menerapkannya dengan baik dan menjadi "kebiasaan" baru dalam memilih dan menentukan metode pembelajaran yang variatif dan kreatif. Untuk itu para guru perlu menambah wawasan pengetahuan dan keterampilan lebih lanjut agar dalam melaksanakan pembelajaran dapat lebih aktif. Dengan demikian peserta didik dapat “menikmati” proses pembelajaran dengan senang tanpa merasa terbebani dengan berbagai tugas yang diberikan. Untuk itu perlu dipikirkan membuat rencana tugastugas siswa secara kreatif agar hasil yang diperoleh pun menjadi hasil kreatif siswa yang keluar dari potensi-potensi terpendamnya. Menerapkan proses pembelajaran yang berbasis kebutuhan dan minat minat siswa akan lebih efektif hasilnya. Untuk itu pahamilah peserta didiknya, galilah kemampuannya, dan lakukanlah proses pembelajaran sesuai dengan potensi dan kebutuhan yang diharapkannya.

\section{DAFTAR PUSTAKA}

Depdiknas. (2005). Peraturan Pemerintah No. 19 Tahun 2005 Tentang Standar Nasional Pendidikan.

Pendidikan Islam. (2009). Data Statistik Pendidikan Madrasah tahun 2012 . 2013. Diakses 24 November 2014 dari

http://emispendis.kemenag.go.id/emi $\underline{\text { s2014/emis_dh/mi_umum.php?kel=1 }}$ embaga

Thaib, M. Amin. (2014). Mutu Pendidikan Madrasah Tsanawiyah. Penamas, Vol 27, No. 2 Juli - September 2014. Diakses 24 November 2014 dari http://blajakarta.kemenag.go.id/pene 418 Peningkatan Kompetensi Pedagogik Guru Melalui Pelatihan Paikem (Pelatihan Pada Guru Mi Dan Mts Di Kabupaten Cianjur) 
Edutech, Tahun 13, Vol.1, No.3, Oktober 2014

litian/bidangpendidikankeagamaan/1

02-mutu-pendidikan-madrasah-

tsanawiyah.html

Hazbi. (2013). Peningkatan Mutu

Pendidikan Madrasah dalam System

Pendidikan Nasional di Kota Palopo

Tahun 2011-2012. Diakses 24 Nov

2014 dari http://www.uin-

alauddin.ac.id/download-

Jurnal\%20Diskursus\%20Islam\%20

Vol\%201\%20No\%203\%20Desembe

r\%202013.55-69.pdf .

Masitoh. Dewi, Laksmi. (2009). Modul

Strategi Pembelajaran. Jakarta:

Depag RI
Kementrian Pendidikan Nasional.

Peraturan Pemerintah No. 74 Tahun

2008 Tentang Guru. Jakarta:

Kementrian Pendidikan Nasional

Kementerian Pendidikan Nasional.

Direktorat Jenderal Peningkatan

Mutu Pendidik dan Tenaga

Kependidikan. 2010. Pedoman

Pelaksanaan Penilaian Kinerja

Guru (PK Guru). Jakarta.

bermutuprofesi.org 